\title{
Sustainable manufacturing strategies: a literature review on additive manufacturing approach
}

\author{
Cauê Gonçalves Mançanares ${ }^{a}$, Eduardo de Senzi Zancula , Paulo Augusto Cauchick Miguel ${ }^{b}$ \\ Universidade de São Paulo \\ buniversidade Federal de Santa Catarina \\ e-mails: cmancanares@gmail.com; ezancul@usp.br; paulo.cauchick@ufsc.br
}

\begin{abstract}
This article aims to provide a literature review regarding sustainability in additive manufacturing. The purpose is to understand the literature main structure concerning sustainability in additive manufacturing in order to identify the field's key challenges. The article employees a systematic literature review on the main topics of sustainability in additive manufacturing. Data were collected in one of the main data bases considering the journal impact factor reports. Articles on the subject were searched and retrieved, and a content analysis was carried out. An evaluation of the challenges in this field was also performed. Additive manufacturing potentially impacts the productive process sustainability in various manners. Several are the research challenges in this field of studies. The literature on sustainability in manufacture presents numerous indicators. However, the literature on sustainability in additive manufacture lacks quantitative research to evaluate these proposed indicators. It is necessary to perform quantitative research in order to evaluate the adequacy of additive manufacturing. This literature review shows multiple additive manufacture impacts on sustainability. Promising studies point out some of these impacts, although there are still some sustainability research gaps on additive manufacturing. This article presents some of these gaps thus allowing researchers to identify research opportunities.
\end{abstract}

Keywords: additive manufacturing, 3-D printing, rapid prototyping, sustainability, manufacturing.

\section{Introduction}

Sustainability has been growingly becoming a main topic in discussions of various fields of study. Corporations around the world show interest to adopt sustainable strategies for their productive systems. Although due to multiple variables that involve these strategies, there is not such a single solution able to answer all of its needs (HOUE; GRABOT, 2009; KUMAR; PUTNAM, 2008; GUO et al., 2008; HSUAN et al., 2008; BARBER, 2007). Engineering has a relevant role in the development of sustainable strategies once the manufacturing activity has an enormous weight in the impacts caused by industries (ANDERSEN; SKJOETTLARSEN, 2009; LEE; KIM, 2009; TAPIERO; KOGAN, 2008; CLARK, 2007; ZHU et al., 2007).

Additive manufacturing is a constructive process of solid tri-dimensional objects starting from layer deposition as opposed to subtractive manufacture (AMERICAN..., 2012). In the last twenty years, these technologies have been widely used for the manufacture of parts for the aeronautical and aerospace industries (METZGER et al., 2013; MARTINA et al., 2012; THOMAS et al., 1996), automotive
(SONG et al., 2002), biomedical (GIANNATSIS; DEDOUSSIS, 2009; SACHLOS; CZERNUSZKA, 2003) and other fields, e.g. architecture.

By its turn additive manufacturing recent technologies have the potential to eliminate traditional manufacturing limitations and to impact, among other things, the sustainability of the production processes (SREENIVASAN; GOEL; BOURELL, 2010; LEVY et al., 2003; KRUTHET al., 1998). The main impacts can be (HUANG et al., 2013; VAYRE et al., 2012; SERRES et al., 2011; HOLMSTROMetal., 2010; BOURELLetal.,2009; REEVES, 2008; MORROW et al., 2007; WALTER et al., 2004; LUO et al., 1999): the more efficient raw material usage, the replacement of non-efficient energy using production processes, the possibility of close to end-user manufacturing, the transportation costs and the supply chain environmental impacts reduction, the design and manufacturing of lighter and more effective parts.

The motivation for this study is to understand the main concepts related to sustainability in additive manufacturing 
and to use a framework to point at the research challenges of sustainability in the additive manufacturing. For achieving this purpose, a portfolio of papers on additive manufacturing sustainability was reviewed.

\section{Research methods}

This study adopted the concepts of a systematic literature review, a bibliometric analysis, and a content analysis. A literature review is a "systematic, explicit and reproducible design for identifying, evaluating, and interpreting the existing body of recorded documents (FINK; KOSECOFF, 1998). This type of review is also important for defining the limits of the planned investigation from a scientific perspective (DANE, 1990).

From a methodological perspective, literature reviews may be understood as content analyses in which quantitative and qualitative aspects are combined to access descriptive and content-related criteria (BREWERTON; MILLWARD, 2001). The following steps were performed in conducting this literature review (SEURING; MÜLLER, 2008): (i) material collection; (ii) descriptive analysis, (iii) category selection, and (iv) material evaluation.

In the material collection step, the publications to be collected were defined and delimitated. The unit of analysis was a single paper. Only articles in peer-reviewed scientific journals in English and with a management focus were retrieved. Two separate searches were conducted, one to identify the articles related to "Sustainability in Manufacture" and the other to find articles related to "Sustainability in Additive Manufacture". The searches were performed primarily as a structured keyword search, in the ISI Web of Knowledge database. The following criteria were used in the search: (i) chronological: the search was not refined by a period of time because doing so would have reduced the research scope; (ii) terminology: terms such as "sustainability in manufacture" and "literature review" in titles, keywords, summary and topics were used as the primary search strings for the first search, and terms like "additive manufacture" and "sustainability" were used for the second search; (iii) field of study: this criterion was limited to Engineering because these terms represent fields of knowledge relevant to the investigation. In the first search, a total of 9 articles were identified in the database after eliminating duplication, while in the second search resulted in a total of 14 articles.

In the descriptive analysis step, formal aspects of the material were accessed, such as the number of publications per year, the name of the journal, the country of origin of the publication, the paper's objective, the industrial sector, the subject, and the research methodology. This process offered a background for subsequent theoretical analysis.

The first search intended to define the structural dimensions to be extracted from the texts. These dimensions form the major topics of the analytic categories concerning sustainability in manufacture (Table 1), aiming at a content-oriented analysis. The 7 issues adopted in this article were proposed by Gunasekaran and Spalanzani (2012): (a) Manufacture sustainability challenges and opportunities; (b) Sustainability in business processes; (c) Sustainability in product development; (d) Sustainability in the supply chain; (e) Sustainability in production operations; (f) Sustainability in the distribution chain; (g) Sustainability by remanufacture, recycling and reverse logistics. The second search aimed to delineate the main findings to be considered in the

Table 1. Research subjects and references on manufacture sustainability.

\begin{tabular}{|c|c|}
\hline Research Subject & References \\
\hline $\begin{array}{l}\text { Manufacture sustainability challenges } \\
\text { and opportunities }\end{array}$ & $\begin{array}{l}\text { Mahler (2007), Clark (2007), Ansett (2007), Jørgensen (2008), Keating et al. (2008), Zhu, Sarkis } \\
\text { and Geng (2005), Hall and Matos (2010), Markley and Davis (2007), Svensson (2007) }\end{array}$ \\
\hline Sustainability in business processes & $\begin{array}{l}\text { Zhu, Sarkis and Geng (2005), Markley and Davis (2007), Svensson (2007), Keating et al. (2008), } \\
\text { Chen and Sheu (2009), Elabras Veiga and Magrini (2009) }\end{array}$ \\
\hline Sustainability in product development & $\begin{array}{l}\text { Maxwell and van der Vorst (2003), Fuller and Ottman (2004), Zhu, Sarkis and Geng (2005), Clark } \\
\text { (2007), Chung, Wee and Yang (2008), Chung and Wee (2008), Houe and Grabot (2009) }\end{array}$ \\
\hline Sustainability in the supply chain & $\begin{array}{l}\text { Chen (2005), Zhu, Sarkis and Geng (2005), Parikka-Alhola (2008), Sigala (2008), Vachon and } \\
\text { Klassen (2006), Andersen and Skjoett-Larsen (2009), Varnäs, Balfors and Faith-Ell (2009), Pagell } \\
\text { and Wu (2009) }\end{array}$ \\
\hline $\begin{array}{l}\text { Sustainability in production } \\
\text { operations }\end{array}$ & $\begin{array}{l}\text { Euclides Filho (2004), Baldwin et al. (2005), Zhu, Sarkis and Geng (2005), Herron and Braiden } \\
\text { (2006), Barber (2007), Clark (2007), Zhu, Sarkis and Lai (2007), Tapiero and Kogan (2008), Lee } \\
\text { and Kim (2009), Andersen and Skjoett-Larsen (2009) }\end{array}$ \\
\hline Sustainability in the distribution chain & $\begin{array}{l}\text { Ravi, Shankar and Tiwari (2005), Zhu, Sarkis and Geng (2005), Sheu et al. (2005), Vachon and } \\
\text { Klassen (2006), Matos and Hall (2007), Zhu, Sarkis and Lai (2007), de Brito et al. (2008), Frota } \\
\text { Neto et al. (2008), Zhu, Sarkis and Lai (2008) }\end{array}$ \\
\hline $\begin{array}{l}\text { Sustainability by remanufacture, } \\
\text { recycling and reverse logistics }\end{array}$ & $\begin{array}{l}\text { Gonzalez-Torre, Adenso-Diaz and Artiba (2004), Jorjani, Leu and Scott (2004), Ravi, Shankar } \\
\text { and Tiwari (2005), Zhu, Sarkis and Geng (2005), and Kim et al. (2006) }\end{array}$ \\
\hline
\end{tabular}


articles related to sustainability in additive manufacture. These findings compile the primary topics of the analytic categories regarding the subject.

The material is then evaluated according to the dimensions identified in the first search. This process should allow for identification of the relevant issues and interpretation of the results. Bibliometric analysis and content analysis were applied. Bibliometric analysis provides insights into the development of a subject, whereas content analysis considers the contents of a communication in an objective, systematic and quantitative manner (WEBER, 1990; KOLBE; BURNETT, 1991). Examining each article, analyses are conducted and opinions are formulated using a theoretical framework that is comprised of this work and the researchers' interpretations. During the content analysis, the reader makes various decisions on how the paper is to be understood (SEURING; MÜLLER, 2008). Risk is reduced by using at least two researchers to analyze the data.

\section{Concepts of sustainability in manufacture}

Sustainability has been growingly becoming a main topic for discussions in different research fields. Corporations are ever more being submitted to pressures of different agents in order to adopt more sustainable production strategies (BARBER, 2007). Nevertheless, no generic solution will be able to solve this problem. This fact derives from the multiplicity of the problem that permeates the sustainable production (HOUE; GRABOT, 2009; KUMAR; PUTNAM, 2008; GUO et al., 2008; HSUAN et al., 2008).

In the academic environment, research can be found in the most diverse areas regarding sustainability. Gunasekaran and Spalanzani (2012) proposed a framework to analyze sustainability in manufacture with 7 primary issues: (a) Manufacture sustainability challenges and opportunities; (b) Sustainability in business processes; (c) Sustainability in product development; (d) Sustainability in the supply chain; (e) Sustainability in production operations; (f) Sustainability in the distribution chain; (g) Sustainability by remanufacture, recycling and reverse logistics. Main research themes in the field of manufacture sustainability are presented in Table 1. as well as main authors.

Next sub-sections describe the main considerations on the subject related to the primary research subjects showed in Table 1. It also includes the main concepts and conclusions found in the articles.

\subsection{Challenges and problems of manufacture sustainability}

Challenges that permeate sustainability come from numerous origins as: governmental industrial standards, political situation, economic situation, labor costs, labor laws, education, terrorist threats, natural disasters, wars, inflation, environmental regulation, competition and, market opportunities Keating et al. (2008), Hall and
Matos (2010), Markley and Davis (2007), Svensson (2007). Jorgensen (2008) describe some tools available to deal with these challenges. Sustainable manufacturing strategies must consider all factors related to the corporation in order to assure stakeholders needs (CLARK, 2007; ZHU et al., 2005). These strategies, then, can become a competitive advantage (ANSETT, 2007; MAHLER, 2007).

\subsection{Sustainability in business processes}

Sustainability in business processes must consider economic, social and environmental aspects of the productive system (VEIGA; MAGRINI, 2009; MARKLEY; DAVIS, 2007; ZHU et al., 2005). Studies in this area specifically consider the environmental and economic implications of the environmental management policies for the increase of the Total Shareholder Value (Chen and Sheu, 2009), as well as, in attaining competitive advantage and business opportunities involving the adoption of techniques considered sustainable for the corporation's performance (SVENSSON, 2007; KEATING et al. ,2008).

\subsection{Sustainability in product development}

Studies regarding this matter point to a change from the use of eco-design to the eco-label use (HOUE; GRABOT, 2009), thus meaning an evolution from good product design practices to standardized certificated restrictions. Some researches consider that the product development stage is responsible for up to $80 \%$ of the environmental impact generated by this given product (MAXWELL; VAN DER VORST, 2003; CLARK, 2007; CHUNG; WEE, 2008), along its life cycle, and further attest the interest of corporations in adopting techniques like The Design for Environment, recycling, reuse and remanufacturing (FULLER; OTTMAN, 2004; ZHU et al., 2005; CHUNG et al., 2008).

\subsection{Sustainability in the supply chain}

In order to keep competitive, corporations must assure the functioning of their worldwide supply networks, involving decisions to manufacture or to outsource, choose suppliers, monitoring and cooperation in the chain (SIGALA, 2008; VACHON; MAO, 2006). As such, chain sustainability must consider the relationship of all involved in its integration and, for this, it needs: internal evaluation criteria for its members: compatible technologies for its operations, cost effectiveness; sustainability evaluation for the client and supplier relations and, transactions control (ANDERSEN; SKJOETT-LARSEN, 2009; PAGELL; WU, 2009; VARNAS et al., 2009).

\subsection{Sustainability in production operations}

The researches studied dealing with sustainability in manufacturing discuss, primarily, the evaluation of the product life cycle (BARBER, 2007; HERRON; 
BRAIDEN, 2006; EUCLIDES FILHO, 2004), in which it has the main role, the pollution prevention in manufacturing (CLARK, 2007), and the cleaner manufacture concept (TAPIERO; KOGAN, 2008). Social, legal and standardization around manufacturing sustainability must be highlighted, thus implying that major attention ought to be given to this stage of the manufacturing process (LEE; KIM, 2009). In the researches some tools are presented in order to handle this problem like: benchmarking, life cycle evaluation, eco-portfolio analysis, environmentally driven design techniques, cleaner manufacture indicators, environmental auditing and, international standards (BALDWIN et al., 2005; ZHU et al., 2005, 2007; ANDERSEN; SKJOETT-LARSEN, 2009).

\subsection{Sustainability in the distribution chain}

Sustainability in the distribution chain is incorporated to the enterprise whenever international standards and laws are adopted (BRITO et al., 2008), and specially aimed to negative environmental impacts, that by its turn, are evaluated by using known techniques like the "from craddle-to-grave" or "end-of-pipe" evaluations (ZHU et al., 2005, 2007, 2008; MATOS; HALL, 2007; RAVI et al., 2005). In this concept of sustainability in the distribution chain, transportation modes play the central role (FROTA NETO et al., 2008; VACHON; MAO, 2006), as they are the main responsible for environmental impacts caused at this stage of the productive process (SHEU et al., 2005).

\subsection{Sustainability by remanufacture, recycling and reverse logistics}

Reverse logistics is mainly used for contaminated residues treatment as such, a fairly present form of sustainability at the corporations and, consequently, well studied (GONZALEZ-TORRE et al., 2004; JORJANI et al., 2004). It is also the first step for the remanufacture (KIM et al., 2006) and recycling, practices that have recently grown due to their use by electronic equipment manufacturers (RAVI et al., 2005). The concept of product responsibility appears at these enterprises, delegating to the manufacturers the final discarding and recycling of these products (ZHU et al., 2005).

The following section discusses the main considerations of the second search performed in the literature review, which is intended to describe the primary outcomes to be considered in the articles related to sustainability in additive manufacture.

\section{Additive manufacture sustainability review}

Additive manufacturing is a relatively new manufacturing process and becoming increasingly interesting for the engineering area (LEVY, 2010). However, studies on processes, applications and implications of the additive manufacturing are still incipient, as such, there are still gaps to be surpassed in the research field (GUO; LEU, 2013). The gaps related to sustainability applied to additive manufacturing are wide and diverse (SREENIVASAN; GOEL; BOURELL, 2010). Therefore, this section intends to delineate the main considerations of researches related to the subject in order to delineate the main issues.

There are potential benefits for sustainability coming from additive manufacturing that can be clearly identified (BOURELL et al., 2009):

a. More effective raw materials usage, coming from the fact that additive manufacturing uses powder or liquid to build a part, rather than using a large block of raw material;

b. Non-efficient electric power intensive production processes replacement as foundry and CNC lathes, by not using ancillary fluids.

c. Possibility to manufacture in any geographic venue , without the need for manpower or special machines, thus allowing manufacturing close to consumer, reducing transportation costs and negative impacts derived from the logistic chain;

d. Lighter parts, thus increasing fuel efficiency in the aeronautical industry;

e. Possibility to manufacture components in complex geometries to be more efficient than the traditional ones.

Additive manufacturing technologies allow mold manufacturing, direct manufacture of parts or, the partial repair of pieces, independently from technical specifications or the knowledge of its conventional manufacturing techniques, thus allowing the reuse of parts that, otherwise, would have been scrapped.

Additive manufacturing allows the manufacture of low weight parts, as it permits that certain components to be manufactured with low fill-in material (LIPSON; MALONE, 2002) or, by allowing that geometries to be used otherwise impossible to be obtained by traditional manufacture (STRANO et al., 2012; VAYRE et al., 2012). The application of these manufacturing techniques admit aerospace components weight reduction, thus reducing both the cost to have aerospace missions sent to outer space and the use of fuel (METZGER et al., 2013; MARTINA et al., 2012).

Some studies indicate that the additive manufacture is able to deliver formerly impossible solutions for the health sector, like the production of custom sized prosthesis and implants (HUANG et al., 2013; OLIVEIRA, 2008; SINGARE et al., 2004). Furthermore, by this technologies it became possible to reduce the development time of prosthesis and implants (HE et al., 2006). Various papers present additive manufacture applications for these objects, like: joint prosthesis (HE et al., 2006a, b), elbows (TRUSCOTT et al., 2007), hip (POPOV; ONUH, 2009; 
RAHMATI et al., 2012), and for the dentistry area (LIU; LEU; SCHMITT, 2006).

On the environmental side, studies considered that additive manufacturing cause fewer impacts than the traditional processes (ZHAO et al., 2010; HUANG et al., 2013). By using the exact amount of material needed to make the part/component and, by not needing ancillary fluids, residues generated by the manufacturing process are reduced (LUOET al., 1999, HUANG et al., 2013). Some case studies evaluated the environmental impacts from traditional parts manufacturing processes and compared them with the manufacturing impacts using additive manufacturing technologies, concluded that these technologies generate up to $70 \%$ less impact (MAZUMDERET al., 1999; MORROW et al., 2007; XIONG; SCHOENUNG, 2010; SERRES et al., 2011).

Studies regarding the additive manufacturing distribution and supply chains further indicate that these technologies have the advantage of production closer to the consumer (REEVES, 2008; HOLMSTROM et al., 2010). Some researches evidence that this feature is an advantage, mainly in the market of high added value replacement parts, such as the aeronautical industry, that has an extremely high inventory cost that might be optimized by using the additive manufacture for the production of these parts (WALTER et al., 2004; HASAN; RENNIE, 2008; HOLMSTROM et al., 2010).

The production closer to the consumer is easier when additive manufacture is used because, one single machine, with a low set-up time, can manufacture fully different parts, thus justifying decentralized parts manufacturing or, in other words, closer to the consumer (HUANG et al., 2013). In this way, transportation costs are reduced, as well as, the negative impacts of this part of the process, besides allowing operating with reduced inventory levels (HOLMSTROM et al., 2010).

Another area exploited in additive manufacturing sustainability studies is remanufacturing. Case studies proof the capability of additive manufacturing to repair parts in the tooling industry and have concluded that, among others, these processes present environmental impacts reduction when compared to traditional processes (MORROW et al., 2007). Furthermore, remanufacturing is justified as a way to answer to needs for social responsibility, follow standards and legislation and, to reduce replacement costs of parts (SELIGER et al., 2006; SEITZ, 2007). However, literature indicates that different strategies are to be adopted in remanufacturing, according to each product, due to differences in the repair procedures and in the (re) obtaining of products, what turns more difficult adopting this practice (OSTLIN et al., 2009).

Next section presents a structure analysis of sustainability in additive manufacture using a framework proposed in the literature studied in section 3 of this paper.

\section{Sustainability challenges in additive manufacture}

The analysis of the researches related to sustainability in additive manufacture permitted the construction of a structured analysis of the subject using a framework proposed by Gunasekaran and Spalanzani (2012) to analyze sustainability in manufacture. Since "Sustainability in Manufacture" is a more developed area the "Sustainability in Additive Manufacture", the framework proposed, presented in Figure 1, is considered robust to analyze this novel manufacture technology.

The framework is based on the seven main themes discussed on manufacture sustainability literature. The authors analysis of each theme was based on the main considerations studied in sections 3 and 4, and the results of the analysis are presented next.

\subsection{Adapting to sustainability challenges and problems}

In order to have the use of additive manufacturing technologies adapted to the sustainability challenges and problems in the enterprise, it is a must to evaluate their internal and external factors. The analysis of factors permits the development of the enterprise strategy, the guidelines and operation plans, further permitting to understand

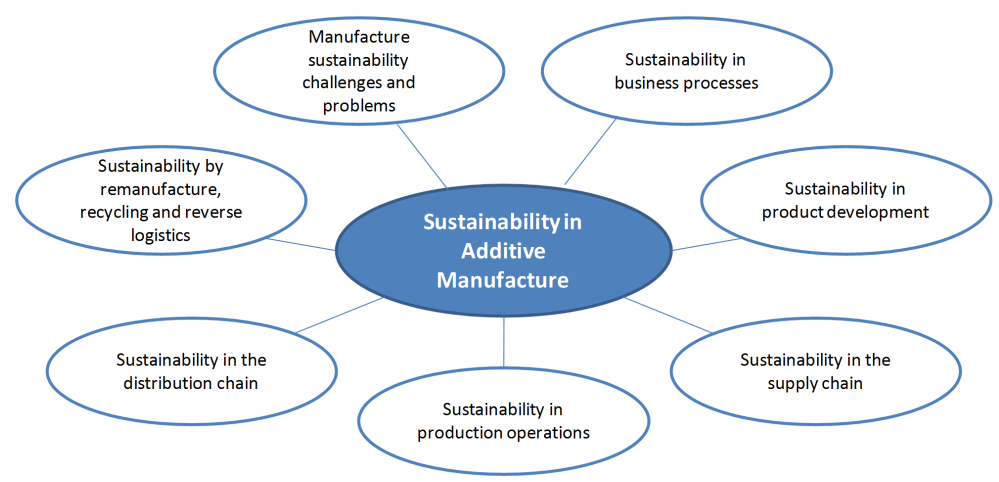

Figure 1. Main researched themes in the manufacturing sustainability field. 
the challenges for its sustainability policies. Such policy must involve the selection of the technologies that will be used, for instance, as they are the main responsible for the environmental impacts generated by the production process. As such, it turns necessary understanding opportunities and restrictions of additive manufacturing, like the production technology of goods or items of the corporation's portfolio.

\subsection{Considering the sustainability of business processes}

The adoption of additive manufacturing technologies must consider the business processes of the corporation. Many techniques developed so as to guarantee the sustainability of business processes, impose restrictions to the technologies applied in manufacturing, like the ISO 14001 (ASSOCIAÇÃO..., 2004), eco-labels and the life cycle evaluations of products can be impacted by the additive manufacturing. It is expected that these recent technologies affect positively the social, environmental and economic impacts of some types of industries, however, few researches have evaluated quantitatively such impacts.

\subsection{Impacts on product development sustainability}

Product development activities should consider production technologies by additive manufacturing at the product development stage. These manufacturing technologies allow for more complex designs to be made, eliminating geometry qand materials restriction existing in traditional manufacturing processes. As such, future impacts might be optimized by incorporating additive manufacturing possibilities in the product design. These impacts involve manufacturing cost reduction, fuel consumption reduction in the aeronautical and airspace industrial operations by designing lighter parts and optimizing raw materials usage to be defined in the product design.

\subsection{Impacts on supply chain sustainability}

Supplier selection can be greatly impacted by adopting additive manufacturing, mainly in regard to production decentralization. As these technologies allow production closer to its consumers, chain suppliers must be able to serve locations closer to the consumer, as well. Production decentralization might generate an even larger need to have compatible technologies in use to manage the chain, as the trend is for more production centers, scattered around.

\subsection{Developments in manufacturing sustainability}

Regarding manufacturing sustainability, additive manufacturing has a central role in the evolution of the product life cycle evaluation, as well as, in pollution prevention. This is due to the fact that these technologies use fewer amounts of materials, do not use additional contaminating fluids and generate fewer residues than the traditional processes. Thus, impacts from additive manufacturing in this field lead to indicators improvement used for the eco-portfolio analysis, environmentally driven design techniques, in cleaner production indicators and in the conformity to standards and legislation.

\subsection{Reduction of negative environmental impacts in the distribution chain}

By means of decentralization coming from the application of additive manufacturing technologies at the enterprises, distance and transportation needs reduction are expected, once manufacturing can be closer to consumption. As such, negative environmental impacts are reduced, at the distribution chain, thus occurring an improvement in the corporation sustainability indicators.

\subsection{Remanufacture made possible}

Among the main advantages brought through additive manufacturing innovations, are the new opportunities for parts repairs, concept also known as remanufacture. This way, environmental and economic impacts will significantly be reduced through parts replacement once, energy, costs and manufacturing impacts coming from a new part are higher than the ones occurring from damaged parts, repaired by additive manufacturing technologies.

\section{Conclusions}

This literature review presents the main considerations and main research challenges of the sustainability in additive manufacturing. Researches on sustainability in manufacturing are already in a higher level of development as the ones aimed at sustainability in additive manufacturing. This way, starting from the main points discussed in the researches on manufacturing, similarly, the main considerations and the main challenges of the research in sustainability in additive manufacturing were presented.

Additive manufacturing processes show numerous potential positive impacts in sustainability. Among the main contributions from the additive manufacturing for a more sustainable productive system are: the reduction of materials usage along manufacturing, low scrap production, no application of auxiliary contaminant fluids during manufacturing, new repair possibilities for parts generated by these technologies, cost and environmental impacts reduction along the distribution and supply chains, possibility to manufacture closer to its consumer, social impacts in the health area with the chance to manufacture custom made implants and prosthesis as well as the new design possibilities for lighter and more efficient products.

Main research voids found are the ones referring to practical applications and quantitative assessments of the additive manufacturing in the productive system. They occur 
from the fact that the additive manufacturing is still in its development stage, with rather small industrial application.

Overall, it can be concluded that the publications involving sustainability and additive manufacturing are promising. Nevertheless, there is still a lot of research to be performed so as to evaluate the impact of these recent impacts in the productive system.

\section{References}

AMERICAN SOCIETY FOR TESTING AND MATERIALS ASTM. ASTM F2792-10: standard terminology for additive manufacturing technologies. West Conshohocken, 2012.

ANDERSEN, M.; SKJOETT-LARSEN, T. Corporate social responsibility in global supply chains. Supply Chain Management: An International Journal, v. 14, n. 2, p. $75-$ 86, 2009. http://dx.doi.org/10.1108/13598540910941948.

ANSETT, A. Mind the gap: a journey to sustainable supply chains. Employ Response Rights Journal, v. 19, n. 4, p. 295-303, 2007. http://dx.doi.org/10.1007/s10672-0079055-X.

ASSOCIAÇÃO BRASILEIRA DE NORMAS TÉCNICAS - ABNT. ABNT NBR ISO 14001: sistema de gestão ambiental: requisitos com orientações para uso. Rio de Janeiro, 2004.

BALDWIN, J. S. et al. Modelling manufacturing evolution: thoughts on sustainable industrial development. Journal of Cleaner Production, v. 13, n. 9, p. 887-902, 2005. http:// dx.doi.org/10.1016/j.jclepro.2004.04.009.

BARBER, J. Mapping the movement to achieve sustainable production and consumption in North America. Journal of Cleaner Production, v. 15, n. 6, p. 490-512, 2007. http:// dx.doi.org/10.1016/j.jclepro.2006.05.010.

BOURELL, D.; LEU, M.; ROSEN, D. Roadmap for additive manufacturing: identifying the future of freeform processing. Austin: The University of Texas, 2009. p. 92.

BREWERTON, P.; MILLWARD, L. Organisational research methods. Great Britain: Sage Publications, 2001.

BRITO, M. P.; CARBOnE, V.; BLANQUART, C. M. Towards a sustainable fashion retail supply chain in Europe: organization and performance. International Journal of Production Economics, v. 114, n. 2, p. 534-553, 2008. http://dx.doi.org/10.1016/j.ijpe.2007.06.012.

CHEN, C.-C. Incorporating green purchasing into the frame of ISO 14000. Journal of Cleaner Production, v. 13, n. 9, p. 927-933, 2005. http://dx.doi.org/10.1016/j. jclepro.2004.04.005.

CHEN, Y. J.; SHEU, J.-B. Environmental-regulation pricing strategies for green supply chain management. Transportation Research Part E, Logistics and
Transportation Review, v. 45, n. 5, p. 667-677, 2009. http://dx.doi.org/10.1016/j.tre.2009.04.010.

CHUNG, C.-J.; WEE, H.-M. Green-component life-cycle value on design and reverse manufacturing in semi-closed supply chain. International Journal of Production Economics, v. 113, n. 2, p. 528-545, 2008. http://dx.doi.org/10.1016/j. ijpe.2007.10.020.

CHUNG, S. L.; WEE, H. M.; YANG, P. C. Optimal policy for a closed-loop supply chain inventory system with remanufacturing. Mathematical and Computer Modelling, v. 48, n. 5-6, p. 867-881, 2008. http://dx.doi. org/10.1016/j.mcm.2007.11.014.

CLARK, G. Evolution of the global sustainable consumption and production policy and the United Nations Environment Programme's (UNEP) supporting activities. Journal of Cleaner Production, v. 15, n. 6, p. 492-498, 2007. http:// dx.doi.org/10.1016/j.jclepro.2006.05.017.

DANE, F. C. (1990). Research methods. Los Angeles: Brooks/ Cole Publishing. p 338.

EUCLIDES FILHO, K. Supply chain approach to sustainable beef production from a Brazilian perspective: livestock production. Science, v. 90, p. 53-61, 2004.

FINK, A.; KOSECOFF, J. How to conduct surveys: a step-bystep guid. Sage, 1998.

FROTA NETO, J. Q. et al. Designing and evaluating sustainable logistics networks. International Journal of Production Economics, v. 111, n. 2, p. 195-208, 2008. http://dx.doi. org/10.1016/j.ijpe.2006.10.014.

FULLER, D. A.; OTTMAN, J. A. Moderating unintended pollution: the role of sustainable product design. Journal of Business Research, v. 57, n. 11, p. 1231-1238, 2004. http:// dx.doi.org/10.1016/S0148-2963(02)00446-0.

GIANNATSIS, J.; DEDOUSSIS, V. Additive fabrication technologies applied to medicine and health care: a review. International Journal of Advanced Manufacturing Technology, v. 40, n. 1-2, p. 116-127, 2009. http://dx.doi. org/10.1007/s00170-007-1308-1.

GONZALEZ-TORRE, P. L.; ADENSO-DIAZ, B.; ARTIBA, $\mathrm{H}$. Environmental and reverse logistics policies in European bottling and packaging firms. International Journal of Production Economics, v. 88, n. 1, p. 95-104, 2004. http:// dx.doi.org/10.1016/S0925-5273(03)00181-6.

GUNASEKARAN, A.; SPALANZANI, A. Sustainability of manufacturing and services: Investigations for research and applications. International Journal of Production Economics, v. 140, n. 1, p. 35-47, 2012. http://dx.doi. org/10.1016/j.ijpe.2011.05.011.

GUO, N.; LEU, M. Additive manufacturing: technology, applications and research needs. Journal of Frontiers of 
Mechanical Engineering, v. 8, n. 3, p. 215-243, 2013. http://dx.doi.org/10.1007/s11465-013-0248-8.

GUO, W. et al. Frequency, moisture and temperature dependent dieletric properties of chickpea flour. Biosystems Engineering, v. 101, n. 2, p. 217-224, 2008.

HALL, J.; MATOS, S. Incorporating impoverished communities in sustainable supply chains. International Journal of Physical Distribution \& Logistics Management, v. 40, n. 1-2, p. 124-147, 2010. http://dx.doi. org/10.1108/09600031011020368.

HASAN, S.; RENNIE, A. E. W. Virtual trading system for rapid manufactured products. In: NATIONAL CONFERENCE ON RAPID DESIGN, PROTOTYPING AND MANUFACTURING, 9., 2008. Proceedings... Lancaster: Lancaster University, 2008.

HE, J.; LI, D.; LU, B. Custom fabrication of a composite hemiknee joint based on rapid prototyping. Rapid Prototyping Journal, v. 12, n. 4, p. 198-205, $2006 \mathrm{~b}$.

HE, Y.; YE, M.; WANG, C. A method in the design and fabrication of exact-fit customized implant based on sectional medical images and rapid prototyping technology. The International Journal of Advanced Manufacturing Technolog, v. 28, n. 5-6, p. 504-508, 2006 a.

HERRON, C.; BRAIDEN, P. M. A methodology for developing sustainable quantifiable productivity improvement in manufacturing companies. International Journal of Production Economics, v. 104, n. 1, p. 143-153, 2006. http://dx.doi.org/10.1016/j.ijpe.2005.10.004.

HOLMSTROM, M. et al. Dynamics of Solar wind protons reflected by the moon. Journal of Geophysical Research, v. 106, n. 27, 2010. http://dx.doi.org/10.1029/2009JA014843.

HOUE, R.; GRABOT, B. Assessing the compliance of a product with an eco- label: from standards to constraints. International Journal of Production Economics, v. 121, n. 1, p. 21-38, 2009. http://dx.doi.org/10.1016/j. ijpe.2008.03.014.

HSUAN, Y. G. et al. Long-term performance and lifetime prediction of Geosynthetics. In: EUROPEAN GEOSYNTHETICS CONFERENCE - EuroGeo, 4., 2008. Edimburg, Scotland. 2008. p. 1-40.

HUANG, S. et al. Additive manufacturing and its societal impact. International Journal of Advanced Manufacturing Technology, v. 67, n. 5-8, p. 1191-1203, 2013. http://dx.doi. org/10.1007/s00170-012-4558-5.

JORGENSEN, T. H. Towards more sustainable management systems: through life cycle management and integration. Journal of Cleaner Production, v. 16, n. 10, p. 1071-1080, 2008. http://dx.doi.org/10.1016/j.jclepro.2007.06.006.

JORJANI, S.; LEU, J.; SCOTT, C. Model for the allocation of electronics compo- nents to reuse options. International
Journal of Production Research, v. 42, n. 6, p. 467-483, 2004. http://dx.doi.org/10.1080/00207540310001632466.

KEATING, B. et al. In pursuit of a sustainable supply chain: insights from Westpac Banking Corporation. Supply Chain Management: An International Journal, v. 13, n. 3, p. 175179, 2008. http://dx.doi.org/10.1108/13598540810871217.

KIM, K. et al. Supply planning model for remanufactur- ing system in reverse logistics environment. Computers \& Industrial Engineering, v. 51, n. 2, p. 279-287, 2006. http:// dx.doi.org/10.1016/j.cie.2006.02.008.

KOLBE, R. H.; BURNETT, M. S. Content-analysis research: An examination of applications with directives for improving research reliability and objectivity. The Journal of Consumer Research, v. 18, n. 2, p. 243-250, 1991. http:// dx.doi.org/10.1086/209256.

KRUTH, J.; LEU, M.; NAKAGAWA, T. Progress in additive manufacturing and rapid prototyping. CIRP Annals: Manufacturing Technology, v. 47, n. 2, p. 525-540, 1998. http://dx.doi.org/10.1016/S0007-8506(07)63240-5.

KUMAR, S.; PUTNAM, V. Cradle to cradle: reverse logistics strategies and opportunities across three industry sectors. International Journal of Production Economics, v. 115, n. 2, p. 305-315, 2008. http://dx.doi.org/10.1016/j. ijpe.2007.11.015.

LEVY, G. N. The role and future of the Laser Technology in the Additive Manufacturing environment. Physics Procedia, v. 5, n. A, p. 65-80, 2010. http://dx.doi.org/10.1016/j. phpro.2010.08.123.

LEVY, G.; SCHINDEL, R.; KRUTH, J. Rapid manufacturing and rapid tooling with Layer Manufacturing (LM) technologies, state of the art and future perspectives. CIRP Annals: Manufacturing Technology, v. 52, n. 2, p. 589-609, 2003. http://dx.doi.org/10.1016/S00078506(07)60206-6.

LIPSON, H.; MALONE, E. (2002). Autonomous selfextending machines for accelerating space exploration. Ithaca: Cornell University.

LIU, Q.; LEU, M.; SCHMITT, S. Rapid prototyping in dentistry: technology and application. International Journal of Advanced Manufacturing Technology, v. 29 , n. $3-4$, p. 317-335, 2006. http://dx.doi.org/10.1007/ s00170-005-2523-2.

LUO, Y. et al. Environmental performance analysis of solid freeform fabrication processes. In: THE 1999 IEEE INTERNATIONAL SYMPOSIUM ON ELECTRONICS AND THE ENVIRONMENT, 1999, Danvers. Proceedings... New York: IEEE, 1999. p. 1-6.

MAHLER, D. The sustainable supply chain. Supply Chain Management Review, v. 11, n. 8, p. 59, 2007. 
MARKLEY, M. J.; DAVIS, L. Exploring future competitive advantage through sustainable supply chains. International Journal of Physical Distribution \& Logistics Management, v. 37, n. 9, p. 763-774, 2007. http://dx.doi. org/10.1108/09600030710840859.

MARTINA, F. et al. Investigation of the benefits of plasma deposition for the additive layer. Journal of Materials Processing Technology, v. 212, n. 6, p. 1377-1386, 2012. http://dx.doi.org/10.1016/j.jmatprotec.2012.02.002.

MATOS, S.; HALL, J. Integrating sustainable development in the supply chain: the case of lifecycle assessment in oil and gas and agricultural biotechnology. Journal of Operations Management, v. 25, n. 6, p. 1083-1102, 2007. http://dx.doi. org/10.1016/j.jom.2007.01.013.

MAXWELL, D.; VAN DER VORST, R. Developing sustainable products and services. Journal of Cleaner Production, v. 11, n. 8, p. 883-895, 2003. http://dx.doi. org/10.1016/S0959-6526(02)00164-6.

MAZUMDER, J.; SCHIFFERER, A.; CHOI, J. Direct materials deposition: designed macro and microstructure. Material Resistance Innovation, v. 3, n. 3, p. 118-131, 1999. http://dx.doi.org/10.1007/s100190050137.

METZGER, P. et al. Affordable, rapid bootstrapping of the space industry and solar system civilization. Journal of Aerospace Engineering, v. 26, n.1, p. 18-29, 2013. http:// dx.doi.org/10.1061/(ASCE)AS.1943-5525.0000236.

MORROW, W. et al. Environmental aspects of laser-based and conventional tool and die manufacturing. Journal of Cleaner Production, v. 15, n. 10, p. 932-943, 2007. http:// dx.doi.org/10.1016/j.jclepro.2005.11.030.

OLIVEIRA, M. F. Aplicações da prototipagem rápida em projetos de pesquisa. 2008. $107 \mathrm{f}$. Dissertação (Mesrado em Engenharia Mecânica)-Faculdade de Engenharia Mecânica, Universidade Estadual de Campinas, Campinas, 2008.

O'STLIN, J.; SUNDIN, E.; BJORKMAN, M. Product lifecycle implications for remanufacturing strategies. Journal of Cleaner Production, v. 17, n. 11, p. 999-1009, 2009. http://dx.doi.org/10.1016/j.jclepro.2009.02.021.

PAGELL, M.; WU, Z. Building a more complete theory of sustainable supply chain management using case studies of 10 exemplars. The Journal of Supply Chain Management, v. 45, n. 2, p. 37-55, 2009. http://dx.doi.org/10.1111/j.1745493X.2009.03162.x.

PARIKKA-ALHOLA, K. Promoting environmentally sound furniture by green public procurement. Ecological Economics, v. 68, n. 1-2, p. 472-485, 2008. http://dx.doi. org/10.1016/j.ecolecon.2008.05.004.

POPOV, I.; ONUH, S. O. Reverse engineering of pelvic bone for hip joint replacement. Journal of Medical Engineering
\& Technology, v. 33, n. 6, p. 454-459, 2009. http://dx.doi. org/10.1080/03091900902952634. PMid:19479609.

RAHMATI, S.; ABBASZADEH, F.; FARAHMAND, F. An improved methodology for design of custom-made hip prostheses to be fabricated using additive manufacturing technologies. Rapid Prototyping Journal, v. 18, n. 5, p. 389400, 2012. http://dx.doi.org/10.1108/13552541211250382.

RAVI, V.; SHANKAR, R.; TIWARI, M. K. Analyzing alternatives in reverse logistics for end-of-life computers: ANP and balanced scorecard approach. Computers \& Industrial Engineering, v. 48, n. 2, p. 327-356, 2005. http:// dx.doi.org/10.1016/j.cie.2005.01.017.

REEVES, P. Additive manufacturing: a supply chain wide response to economic uncertainty and environmental sustainability. Derbyshire: Econolyst, 2008.

SACHLOS, E.; CZERNUSZKA, J. T. Making tissue engineering scaffolds work. Review: the application of solid freeform fabrication technology to the production of tissue engineering scaffolds. European Cells \& Materials, v. 5, p. 29-39, 2003. PMid:14562270.

SEITZ, M. A critical assessment of motives for product recovery: the case. Journal of Cleaner Production, v. 15, n. 11-12, p. 1147-1157, 2007. http://dx.doi.org/10.1016/j. jclepro.2006.05.029.

SELIGER, G.; KERNBAUM, S.; ZETTL, M. Remanufacturing Approaches Contributing to Sustainable Engineering. Gestão \& Produção, v. 13, n. 3, p. 367-384, 2006. http:// dx.doi.org/10.1590/S0104-530X2006000300002. [Tech. magazine]

SERRES, N. et al. Environmental comparison of MESOCLAD process and conventional machining implementing life cycle assessment. Journal of Cleaner Production, v. 19, n. 9-10, p. 1117-1124, 2011. http://dx.doi.org/10.1016/j. jclepro.2010.12.010.

SEURING, S.; MÜLLER, M. From a literature review to a conceptual framework for sustainable supply chain management. Journal of Cleaner Production, v. 16, n. 15, p. 1699-1710, 2008. http://dx.doi.org/10.1016/j. jclepro.2008.04.020.

SHEU, J.-B.; CHOU, Y.-H.; HU, C.-C. An integrated logistics operational model for green-supply chain management. Transportation Research, v. 41, n. 4, p. 287-313, 2005. http://dx.doi.org/10.1016/j.tre.2004.07.001.

SIGALA, M. A supply chain management approach for investigating the role of tour operators on sustainable tourism: the case of TUI. Journal of Cleaner Production, v. 16, n. 15, p. 1589-1599, 2008. http://dx.doi.org/10.1016/j. jclepro.2008.04.021.

SINGARE, S. et al. Design and fabrication of custom mandible titanium tray based on rapid prototyping. 
Medical Engineering \& Physics, v. 26, n. 8, p. 671-676, 2004. http://dx.doi.org/10.1016/j.medengphy.2004.06.001. PMid:15471695.

SONG, Y. et al. Manufacturing of the die of an automobile deck part based on rapid prototyping and rapid tooling technology. Journal of Materials Processing Technology, v. 120, n. 1-3, p. 237-242, 2002. http://dx.doi.org/10.1016/ S0924-0136(01)01165-7.

SREENIVASAN, R.; GOEL, A.; BOURELL, D. Sustainability issues in laser-based additive manufacturing. Physics Procedia, v. 5, p. 81-90, 2010. http://dx.doi.org/10.1016/j. phpro.2010.08.124.

STRANO, G. et al. A new approach to the design and optimisation of support structures in additive manufacturing. International Journal of Advanced Manufacturing Technology, v. 66, n. 9-12, p. 1247-1254, 2013. http:// dx.doi.org/10.1007/s00170-012-4403-x.

SVENSSON, G. Aspects of sustainable supply chain management (SSCM): conceptual framework and empirical example. Supply Chain Management. International Journal, v. 12, n. 4, p. 262-266, 2007.

TAPIERO, C.; KOGAN, K. Vertical pricing competition in supply chains: the effect of production experience and coordination. International Transactions in Operational Research, v. 15, n. 4, p. 461-479, 2008. http://dx.doi. org/10.1111/j.1475-3995.2008.00645.x.

THOMAS, C. L. et al. Rapid prototyping of large scale aerospace structures. In: AEROSPACE APPLICATIONS CONFERENCE, 4., 1996, Aspen. Proceedings... Aspen: IEEE, 1996. p. 219-230.

TRUSCOTT, M. et al. Using RP to promote collaborative design of customised medical implants. Rapid Prototyping Journal, v. 13, n. 2, p. 107-114, 2007. http://dx.doi. org/10.1108/13552540710736795.

VACHON, S.; MAO, Z. Extending green practices across the supply chain: the impact of upstream and downstream integration. International Journal of Operations \& Production Management, v. 25, n. 7, p. 795-821, 2006.

VARNAS, A.; BALFORS, B.; FAITH-ELL, C. Environmental consideration in procure- ment of construction contracts: current practice, problems and opportunities in green procurement in the Swedish construction industry. Journal of Cleaner Production, v. 17, n. 13, p. 1214-1222, 2009. http://dx.doi.org/10.1016/j.jclepro.2009.04.001.

VAYRE, B.; VIGNAT, F.; VILLENEUVE, F. Designing for additive manufacturing. Procedia CIRP, v. 3, p. 632-637, 2012. http://dx.doi.org/10.1016/j.procir.2012.07.108.

VEIGA, L. B. E.; MAGRINI, A. Eco-industrial park development in Rio de Janeiro, Brazil: a tool for sustainable development. Journal of Cleaner Production, v. 17, n. 7, p. 653-661, 2009. http://dx.doi.org/10.1016/j. jclepro.2008.11.009.

WALTER, M. et al. Visualization of protein interactions in living plant cells using bimolecular fluorescence complementation. The Plant Journal, v. 40, n. 3, p. 428-438, 2004. http://dx.doi.org/10.1111/j.1365-313X.2004.02219.x. PMid:15469500.

WEBER, R. P. (1990). Basic content analysis. Newbury Park: Sage Publications.

XIONG, Y.; SCHOENUNG, J. Process cost comparison for conventional and near net-shape cermet fabrication. Advanced Engineering Materials, v. 12, p. 235-241, 2010.

ZHAO, F. et al. Environmental assessment of laser assisted manufacturing: case studies on laser shock peening and laser assisted turning. Journal of Cleaner Production, v. 18, n. 13, p. 1311-1319, 2010. http://dx.doi.org/10.1016/j. jclepro.2010.04.019.

ZHU, Q.; SARKIS, J.; GENG, Y. Green supply chain management in China: pressures, practices and performance. International Journal of Operations \& Production Management, v. 25, n. 5, p. 449-468, 2005. http://dx.doi. org/10.1108/01443570510593148.

ZHU, Q.; SARKIS, J.; LAI, K.-H. Green supply chain management implications for closing the loop. Transportation Research Part E, Logistics and Transportation Review, v. 44, n. 1, p. 1-18, 2008. http:// dx.doi.org/10.1016/j.tre.2006.06.003.

ZHU, Q.; SARKIS, J.; LAI, K.-H. Green supply chain management: pressures, practices and performance within the Chinese automobile industry. Journal of Cleaner Production, v. 15, n. 11-12, p. 1041-1052, 2007. http:// dx.doi.org/10.1016/j.jclepro.2006.05.021. 